\title{
Modulation of arsenic-induced oxidative stress and protein metabolism by diphenyleneiodonium, 24-epibrassinolide and proline in Glycine max $\mathrm{L}$.
}

\author{
Vibhuti Chandrakar', Amit Dubey ${ }^{2}$, Sahu Keshavkant ${ }^{1 \star}$ \\ ${ }^{1}$ School of Studies in Biotechnology, Pt. Ravishankar Shukla University, Raipur 492 010, India \\ ${ }^{2}$ Central Laboratory Facility, Chhattisgarh Council of Science and Technology, Raipur 492 010, India
}

\begin{abstract}
Arsenic (As)-toxicity is a major constraint for crop production. The present study was intended to examine the comparative ameliorative effects of diphenyleneiodonium (DPI), 24-epibrassinolide (EBL) and proline (Pro) on As-stress in Glycine max L. Seeds of Glycine max L. were subjected to As $(100 \mu \mathrm{M})$ singly, and together with DPI $(10 \mu \mathrm{M})$, EBL $(0.5 \mu \mathrm{M})$ or Pro $(10 \mathrm{mM})$, for five days, and were then analyzed. Experimental results showed that As treatment caused a substantial fall in growth traits like germination percentage, radicle length and dry mass, which was accompanied by As accumulation. Additionally, As application also revealed reduced viability, total protein content and activities of antioxidative enzymes (superoxide dismutase, catalase and ascorbate peroxidase), while it increased the levels of total sugar, proline and oxidative stress markers such as electrolyte leakage, reactive oxygen species, lipid oxidized products, protein carbonyls and hydroperoxides, Amadori and Maillard reaction products, malondialdehyde-/4-hydroxy-2-nonenal-protein adducts, protease and proteasome. Isozymes of antioxidative enzymes were also observed to be altered considerably under As-stress. Impressively, DPI, EBL and Pro played their role as protective agents, hence caused enhanced growth and reduced As accumulation. These protective chemicals also improved the viability, accruals of total protein, total sugar and endogenous proline, and activities of antioxidants, while they reduced the levels of oxidative stress markers. Our findings demonstrated the involvement of DPI, EBL and Pro in As-stress tolerance in Glycine max L. Further, Pro appears to be superior to DPI and EBL, in alleviating As-induced responses in Glycine max L.
\end{abstract}

Keywords: arsenic, diphenylene iodonium, 24-epibrassinolide, oxidative stress, proline, protein metabolism, reactive oxygen species

\section{Introduction}

Arsenic (As) is a hazardous metalloid, which ranks $20^{\text {th }}$ in the Earth's crust and is ubiquitously present in the natural environment. Its concentration above the permissible limit (10 $\left.\mu \mathrm{g} \mathrm{L}^{-1}, \mathrm{WHO}\right)$ hampers the normal growth, development and overall metabolic functioning of plants, resulting in toxicity symptoms. The symptoms of As-stress in plants include reduced growth and biomass accumulation, leaf gas exchange, chlorophyll synthesis and thereby photosynthesis, nutrient supply, cellular water potential, protein turnover, and enzymic dysfunction (Chandrakar et al. 2016a). A plant's root serves as the foremost and most susceptible site for the perception of abiotic stress responses including Astoxicity. After entering into the plant's body, As readily binds with sulfhydryl groups of both proteins and enzymes, thereby perturbing the cellular metabolism and inhibiting enzy- matic activities (Farooq et al. 2015). A well-known consequence of As-toxicity is over-production of reactive oxygen species (ROS) such as superoxide $\left(\mathrm{O}_{2}{ }^{-}\right)$, hydroxyl radical $(\cdot \mathrm{OH})$ and hydrogen peroxide $\left(\mathrm{H}_{2} \mathrm{O}_{2}\right)$, affecting the oxidative condition inside the plants (Siddiqui et al. 2015, Chandrakar et al. 2016b). This over-produced ROS are largely shown to attack cellular macromolecules such as lipids, proteins, nucleic acids, etc. (Chandrakar et al. 2017a).

The polyunsaturated fatty acid (PUFA) fractions of membrane lipids are the prime targets of ROS attack (Chandrakar et al. 2016b). Accruals of malondialdehyde (MDA) and 4-hydroxy-2-nonenal (HNE), chief products and biomarkers of lipid peroxidation reaction in stressed cells, are linked directly with the disturbed integrity or leakiness of the membranes (Yadu et al. 2016). Accumulation of ROS has also been shown to cause reduced fluidity of cellular membranes and

* Corresponding author, e-mail: sneza.dragicevic@t-com.me 
thereby increased leakage of electrolytes, damage to membrane proteins, loss of tissue viability and inactivation of both enzymes and receptors of it (Kaur et al. 2012). Exposure to ROS is shown to modify the structure of proteins, oxidation of side chain groups, cross-linking, generation of new reactive groups and fragmentation of backbone (Chandrakar et al. 2016b). Moreover, direct oxidation of a number of amino acids, particularly His, Lys, Arg, Pro and Thr, gives rise to protein carbonyls (PCO), which are quite susceptible to proteolysis (Parkhey et al. 2014a). In addition, protein hydroperoxides (PrOOHs), the most abundant and reactive molecules, are also produced as a derivative of ROS-mediated oxidation of proteins, and are shown to contribute to PCO turnover (Mallick et al. 2013). Moreover, in stressed cells, proteins are also shown to combine readily with lipid peroxidized products such as malondialdehyde (MDA) and 4-hydroxy-2-nonenal (HNE), thus forming cytotoxic compounds MDA-/HNE-protein adducts, which are genotoxic in nature and are resistant to proteases (Parkhey et al. 2014a, Chandrakar et al. 2017b). Proteasomes are shown to be involved actively in elimination of degraded, aggregated and/ or misfolded proteins (Karmous et al. 2014). In addition to oxidation, proteins also undergo non-enzymatic modification following Amadori and Maillard reaction pathways (Murthy and Sun 2000). In the Amadori reaction, reducing sugars attack on amino groups of proteins, while the Maillard reaction involves subsequent interactions and/ or rearrangements of Amadori products to form brown colored polymeric cytotoxic products (Murthy and Sun 2000). These glycated products lead to alterations in metabolic processes, damage to DNA, failure of repairing system and loss of enzymatic function as well, consequently, of loss of cell viability (Parkhey et al. 2014a). Literature pertaining to glycation of protein in any of the plant species subjected to heavy metal/ metalloid stress is absolutely lacking. Therefore, the biochemical mechanisms governing As-induced protein metabolism need to be elucidated empirically. Fortunately, plants have an intricate and impressive array of ROS processing systems comprising superoxide dismutase (SOD), catalase (CAT), ascorbate peroxidase (APX), etc., which often impart abiotic stress tolerance to plants (Nikolic et al. 2014). However, this defensive system is often insufficient to withstand severe stress conditions. Hence, efforts have been invested in finding exogenous additives to counter ROS-induced injury symptoms and enhance stress tolerance in plants and their parts.

Diphenyleneiodonium (DPI) is one of the potential ROS scavengers in plants, providing tolerance against drought-induced oxidative condition (Jiang and Zhang 2002). It lessens the ROS level by inhibiting NADPH oxidase and nitric oxide synthase, enzymes of $\mathrm{O}_{2}{ }^{-}$biosynthetic pathway (Ye et al. 2012). Although, having the potential to scavenge ROS, exogenous application of DPI against any metal/ metalloidinduced stresses, still remains to be revealed completely in plants. Thence, exogenous use of DPI to compensate for Asinduced injuries in plants is a matter of scientific interest. Therefore, DPI was used in the current study to provide tolerance against oxidative stress by lowering the accumulation of As-induced ROS in Glycine max L. Similarly, 24-epibrassinolide (EBL) has been shown to regulate various metabolic processes such as seed germination, cell division and elongation, ions uptake, membrane integrity, nucleic acid and protein syntheses, photosynthesis, etc. in plants (Fariduddin et al. 2015). Exogenous addition of EBL enhances antioxidant enzyme expression, thus protecting the plants from oxidative injury. 24-epibrassinolide is well known for the synthesis of phytochelatins, a short polypeptide that binds to metals/ metalloids and sequesters them inside the cell. Studies have confirmed the efficacy of EBL in increasing plant tolerance to a number of abiotic stresses such as Mn-toxicity (Fariduddin et al. 2015), chilling stress (Wu et al. 2015), etc., but its role in As-toxicity conditions remains to be resolved fully. Further, under abiotic stress conditions, plants mostly accumulate osmolytes such as proline (Pro), which serves as osmoprotectant, membrane plasticizer and direct scavenger of free radicals (Yadu et al. 2016). Additionally, it also acts as a momentary source of both carbon and nitrogen that helps in the recovery of plants in stressful conditions. It also prevents enzymes from denaturation caused under stressful conditions, hence can be used against As, which readily binds with sulfhydryl groups and inactivates enzymes and proteins. Thus, Pro may play an imperative role in enhancing plant stress tolerance to various abiotic stresses (Hayat et al. 2012, Agami 2014).

Our previous study has shown that oxidative stress is a major component in the expression of As-toxicity in Glycine max L. (Chandrakar et al. 2016a). Therefore, in order to explore the possibility of whether the ROS scavengers viz DPI, EBL or Pro, could be used to alleviate As-induced oxidative injury, the present study was aimed at examining the comparative effects of DPI, EBL and Pro on growth and development, As accumulation, tissue viability, oxidative stress markers (electrolyte leakage, ROS, MDA, HNE, endogenous Pro and total sugar), total protein and its oxidized products (PCO, PrOOH, Amadori and Maillard reaction products and MDA-/HNE-protein adducts), activities of protease and proteasome, and responses of antioxidant enzymes in Asstressed Glycine max L.

\section{Materials and methods}

\section{Seed collection, treatments and germination assessment}

Fresh seeds of Glycine max L. were collected from the farmers of Kabirdham (N22 $01^{\prime}$, E $\left.81^{\circ} 23^{\prime}, 353 \mathrm{MSL}\right), 110 \mathrm{~km}$ to the south of Raipur. Healthy seeds were sorted out and stored in plastic trays in laboratory conditions $\left(26 \pm 2{ }^{\circ} \mathrm{C}\right.$, relative humidity $52 \pm 2 \%$ ) for experimental usage. Assorted seeds were surface sterilized applying $1 \%(\mathrm{v} / \mathrm{v})$ sodium hypochlorite solution for $5 \mathrm{~min}$ and then washed thoroughly $(5$ times) with MilliQ water (MW) (Millipore, Gradient A-10, USA). Subsequently, seeds $(\mathrm{n}=80)$ were kept for germination on sterile boxes $(30 \times 15 \times 15 \mathrm{~cm})$ and over filter paper towels soaked with $100 \mu \mathrm{M}$ of As $\left(\mathrm{NaAsO}_{2}\right.$ was used as source). In addition, the same number of seeds were also germinated over paper towels moistened with DPI $(10 \mu \mathrm{M})$, EBL $(0.5$ 
$\mu \mathrm{M})$ and Pro (10 $\mathrm{mM})$ separately, and in their combination with As $(100 \mu \mathrm{M})$. The dose of As chosen was the concentration at which Glycine max L. seeds revealed toxicity symptoms in the form of $26 \%$ germination only. Moreover, the doses of DPI, EBL and Pro selected were those in which 58\%, $70 \%$ and $78 \%$ respectively germination percentage against As-stress $(100 \mu \mathrm{M})$ in Glycine max L. were noted. All the seeds were allowed to grow in darkness at $26 \pm 2{ }^{\circ} \mathrm{C}$, for 5 days. The solution ( $10 \mathrm{~mL}$ each) was supplied to the growing seeds after every $24 \mathrm{~h}$ until day 5 . All the analyses were performed in five replicates, and repeated twice. Only seeds having radicles $5 \mathrm{~mm}$ long were considered germinated, and were scored (\%) on fifth day of incubation.

\section{Radicle length and biomass}

To assess change in length (RL) and dry mass (DM), the radicles were removed precisely from the seeds, blotted gently over a filter paper, and changes in length and DM were monitored (Chandrakar et al. 2016a).

\section{Estimation of As content}

To determine As content, shade dried tissues (100 mg) were digested in a mixture of conc. $\mathrm{HNO}_{3}, \mathrm{H}_{2} \mathrm{O}_{2}$ and $\mathrm{H}_{2} \mathrm{O}$ $(3 / 2 / 10, \mathrm{v} / \mathrm{v} / \mathrm{v})$ at $80^{\circ} \mathrm{C}$, until a clear solution was obtained, and made up to $15 \mathrm{~mL}$ with MW (Chandrakar et al. 2016a). Arsenic content was determined using an atomic absorption spectrometer coupled to a hydride generation system (Agilent, AA240, USA). The standard reference materials of metals (1.19773.0500, Merck, Darmstadt, Germany) were used for calibration and quality assurance for analysis.

\section{Reactive oxygen species}

For $\mathrm{O}_{2}{ }^{--}$estimation, $0.2 \mathrm{~g}$ radicles were homogenized with cold $\left(4^{\circ} \mathrm{C}\right)$ sodium phosphate buffer $(0.2 \mathrm{M}, \mathrm{pH} 7.2)$ comprising diethyldithiocarbamate $\left(10^{-3} \mathrm{M}\right)$ to inhibit active SOD (Sangeetha et al. 1990). The homogenate was centrifuged $\left(10000 \mathrm{rpm}, 10 \mathrm{~min}, 4^{\circ} \mathrm{C}\right.$ ) and in the collected supernatant, $\mathrm{O}_{2}{ }^{--}$was estimated by its capacity to reduce nitro blue tetrazolium (NBT, $2.5 \times 10^{-4} \mathrm{M}$ ) at $540 \mathrm{~nm}$ using an UV-Vis spectrophotometer (Lambda-25, Perkin Elmer, USA), and expressed as $\mu \mathrm{mol} \mathrm{O}_{2}{ }^{--} \mathrm{min}^{-1} \mathrm{~g}^{-1}$ fresh mass (FM).

To measure ${ }^{\circ} \mathrm{OH}$, radicles $(0.2 \mathrm{~g})$ were homogenized in $2 \mathrm{~mL}$ of phosphate buffer $(10 \mathrm{mM}, \mathrm{pH} 7.4)$ consisting of 15 $\mathrm{mM} 2$-deoxyribose and incubated at $37^{\circ} \mathrm{C}$ for $2 \mathrm{~h}$. After centrifugation (12000 rpm, $15 \mathrm{~min}$ ), $0.7 \mathrm{~mL}$ of supernatant was mixed with $3 \mathrm{~mL}$ of $0.5 \%(\mathrm{w} / \mathrm{v})$ thiobarbituric acid (TBA, prepared in $5 \mathrm{mM} \mathrm{NaOH}$ ) and $1 \mathrm{~mL}$ of glacial acetic acid (Kaur et al. 2012). This reaction mixture was heated at 100 ${ }^{\circ} \mathrm{C}$ for $30 \mathrm{~min}$ and then cooled immediately $\left(4^{\circ} \mathrm{C}, 10 \mathrm{~min}\right)$. Absorbance was recorded at $532 \mathrm{~nm}$ and corrected for nonspecific absorbance at $600 \mathrm{~nm}$. Content of $\mathrm{OH}$ was calculated using an extinction coefficient of $0.155 \mathrm{~mol}^{-1} \mathrm{~cm}^{-1}$ and expressed as nmol g-1 FM.

To assess $\mathrm{H}_{2} \mathrm{O}_{2}$ content, $0.2 \mathrm{~g}$ of radicles were extracted with $2 \mathrm{~mL}$ of $0.1 \%(\mathrm{w} / \mathrm{v})$ trichloroacetic acid (TCA) and cen- trifuged at $12000 \mathrm{rpm}$ for $15 \mathrm{~min}$ (Velikova et al. 2000). In an aliquot $(0.75 \mathrm{~mL})$ of supernatant, equal volumes of both phosphate buffer $(10 \mathrm{mM}, \mathrm{pH} 7)$ and potassium iodide (1 M) were added and absorbance of the sample was read at 390 nm. Content of $\mathrm{H}_{2} \mathrm{O}_{2}$ was calculated using an extinction coefficient $0.28 \mu \mathrm{mol}^{-1} \mathrm{~cm}^{-1}$ and was expressed as $\mu \mathrm{mol} \mathrm{g}^{-1} \mathrm{FM}$.

\section{Viability assessment}

Ten randomly selected radicles were immersed in the $0.5 \%(\mathrm{w} / \mathrm{v})$ 2,3,5-triphenyl tetrazolium chloride (TTC) solution, and incubated in the dark for $24 \mathrm{~h}$ at room temperature (Lakon 1949). Afterwards, seedlings were homogenized in $2 \mathrm{~mL}$ of ethanol and centrifuged (5000 rpm, $10 \mathrm{~min}$ ). In the collected supernatant, reduced TTC was assayed at 520 nm using ethanol as blank, and values were expressed as $\mathrm{A}_{520} \mathrm{~g}^{-1} \mathrm{FM}$.

\section{Leakage of electrolytes}

Rate of electrolyte leakage was measured following the protocol of Blum and Ebercon (1981). $0.2 \mathrm{~g}$ of radicles was immersed in $20 \mathrm{~mL}$ of $\mathrm{MW}$ and kept on an orbital shaker (50 rpm, $24 \mathrm{~h})$. Thereafter, electrical conductance of the solution was measured $\left(\mathrm{C}_{0}\right)$ using a EC-TDS analyzer (CM183, Elico, India). Then, the radicles were boiled for $20 \mathrm{~min}$ and electrical conductance was once again determined $\left(\mathrm{C}_{1}\right)$. Results were expressed as percentages of electrolyte leakage $=\mathrm{C}_{0} / \mathrm{C}_{1} \times 100$.

\section{Lipid peroxidized products}

For the estimation of MDA, $0.1 \mathrm{~g}$ radicles was crushed with 20\% (w/v) TCA consisting 0.5\% (w/v) TBA (Velikova et al. 2000). Homogenate was boiled for $30 \mathrm{~min}$, cooled and centrifuged (11000 rpm, $10 \mathrm{~min}$ ). Absorbance of the supernatant was recorded at $532 \mathrm{~nm}$ and MDA was estimated following the extinction coefficient of $157 \mathrm{mmol}^{-1} \mathrm{~cm}^{-1}$. Data was expressed as nmol g-1 FM.

To monitor HNE, $0.1 \mathrm{~g}$ radicles was homogenized in borate buffer $(0.2 \mathrm{M}, \mathrm{pH} 7.4)$ and TCA $(10 \%, \mathrm{w} / \mathrm{v})$. The homogenate was centrifuged (11000 rpm, $20 \mathrm{~min}, 4^{\circ} \mathrm{C}$ ), and the supernatant was mixed with 2,4-dinitrophenylhydrazine (DNPH, 1\%, w/v) prepared in $\mathrm{HCl}(0.5 \mathrm{M})$, and incubated at room temperature for $2 \mathrm{~h}$. It was then extracted with hexane, and dried under liquid nitrogen. Residue was dissolved in methanol and absorbance was recorded at $350 \mathrm{~nm}$ (Ray et al. 2007). An extinction coefficient of $13750 \mathrm{~mol}^{-1} \mathrm{~cm}^{-1}$ was used to calculate HNE content and data was expressed as $\mathrm{mmol} \mathrm{g}^{-1} \mathrm{FM}$.

\section{Protein extraction and quantification}

$0.2 \mathrm{~g}$ radicles were extracted with $2 \mathrm{~mL}$ of $10 \mathrm{mM}$ phosphate buffer ( $\mathrm{pH} 7.2$ ) containing $1 \mathrm{mM}$ EDTA, $2 \mathrm{mM}$ dithiothreitol and $0.2 \%(\mathrm{v} / \mathrm{v})$ Triton X-100, and centrifuged (1000 rpm, $20 \mathrm{~min}, 4^{\circ} \mathrm{C}$ ). Supernatant thus obtained was used for estimations of protein content and antioxidant enzymes. Protein content was assessed following Bradford (1976). Bo- 
vine serum albumin was used to prepare a standard curve. Content of protein was expressed as $\mathrm{mg} \mathrm{g}^{-1} \mathrm{FM}$.

\section{Estimation of protein carbonyl}

Carbonyl groups were monitored, following their reactivity with DNPH to form hydrazones (Levine et al. 1994). The extracted protein $(500 \mu \mathrm{L})$ was incubated with $200 \mu \mathrm{L}$ each of $0.03 \%(\mathrm{v} / \mathrm{v})$ Triton X-100 and $1 \%(\mathrm{w} / \mathrm{v})$ streptomycin sulphate for $20 \mathrm{~min}$. After centrifugation (11000 rpm, 10 min, $4^{\circ} \mathrm{C}$ ), supernatants were mixed with $10 \mathrm{mM} \mathrm{DNPH}$, prepared in $2 \mathrm{M} \mathrm{HCl}$. The blank was incubated with $2 \mathrm{M}$ $\mathrm{HCl}$ only. After $1 \mathrm{~h}$ of incubation, proteins were precipitated with $10 \%(\mathrm{w} / \mathrm{v})$ TCA. The pellets were finally dissolved in 6 $\mathrm{M}$ guanidine hydrochloride, prepared in $20 \mathrm{mM}$ potassium phosphate buffer ( $\mathrm{pH} 2.3$ ), and absorbance was recorded at $370 \mathrm{~nm}$. Content of PCO was calculated using extinction coefficient $22000 \mathrm{~mol}^{-1} \mathrm{~cm}^{-1}$ and values were expressed in terms of mol mg ${ }^{-1}$ protein.

\section{Determination of protein hydroperoxide}

To measure PrOOH content, isolated protein was initially dissolved in $25 \mathrm{mM}$ sulphuric acid. To it, $5 \mathrm{mM}$ each of ferrous ammonium sulphate, and xylenol orange prepared in $25 \mathrm{mM}$ sulphuric acid were added. This mixture was incubated for $1 \mathrm{~h}$ in the dark, and then centrifuged (12000 rpm, $20 \mathrm{~min}$ ) (Gay et al. 1999). Absorbance of the supernatant was recorded at $560 \mathrm{~nm}$, and content of $\mathrm{PrOOH}$ was calculated using the extinction coefficient of $35.5 \mathrm{mmol}^{-1} \mathrm{~cm}^{-1}$. Amount of $\mathrm{PrOOH}$ was referred as $\mathrm{mmol} \mathrm{mg^{-1 }}$ protein.

\section{Measurements of MDA-/HNE-protein adducts}

An isolated protein pellet $\left(5 \mathrm{mg} \mathrm{mL}^{-1}\right)$ was re-dissolved in sodium phosphate buffer $(0.2 \mathrm{M}, \mathrm{pH}$ 7.4). Fluorescence for MDA-protein adducts ( $395 \mathrm{~nm}$ excitation/460 nm emission) and HNE-protein adducts ( $356 \mathrm{~nm}$ excitation/460 nm emission) was determined using a fluorescence spectrophotometer (LS-45, Perkin Elmer, USA) (Chairpotto et al. 1997). Values were expressed as unit fluorescence $\mathrm{mg}^{-1}$ protein.

\section{Monitoring of total sugar}

For total sugar estimation, $0.2 \mathrm{~g}$ radicles were extracted with sodium phosphate buffer ( $50 \mathrm{mM}, \mathrm{pH} 7.2)$ and centrifuged (12000 rpm, $15 \mathrm{~min}, 4^{\circ} \mathrm{C}$ ) (Spiro 1966). The supernatant thus obtained was mixed with anthrone $(0.2 \%, \mathrm{w} / \mathrm{v})$, and allowed to stand for $10 \mathrm{~min}$ in a water bath $\left(100^{\circ} \mathrm{C}\right)$. The sample was cooled and the absorbance was read at $620 \mathrm{~nm}$, and denoted as $\mathrm{mg} \mathrm{g}^{-1} \mathrm{FM}$.

\section{Determinations of Amadori and Maillard reaction products}

Radicles $(0.2 \mathrm{~g})$ were macerated with sodium phosphate buffer ( $50 \mathrm{mM}$, pH 7.2), consisting of $10 \%$ (w/v) streptomycin sulphate, dissolved in $50 \mathrm{mM}$ HEPES buffer ( $\mathrm{pH}$ 7.2) (Murthy and Sun 2000). The homogenate was centrifuged $(11000 \mathrm{rpm}, 15 \mathrm{~min})$ and streptomycin sulphate $(200 \mu \mathrm{L})$ was once again added to it and then re-centrifuged. Thereafter, proteins were precipitated with ammonium sulphate $\left(0.55 \mathrm{~g} \mathrm{~mL}^{-1}\right)$ and were re-dissolved in sodium phosphate buffer $(50 \mathrm{mM}, \mathrm{pH}$ 7.2). It was then used for Amadori and Maillard reaction products measurement. To measure the Amadori reaction product, the isolated protein was mixed with NBT (0.5 mM in $100 \mathrm{mM}$ sodium carbonate, $\mathrm{pH} 10.3)$ and incubated in a water bath $\left(40^{\circ} \mathrm{C}\right)$. Absorbance was recorded at $550 \mathrm{~nm}$, after 10 and 20 min of incubation. Absorbance $(\triangle \mathrm{OD})$ value was considered as the measure of the Amadori reaction product. To monitor the Maillard reaction product, isolated proteins were scanned at excitation wavelength $375 \mathrm{~nm}$ and emission wavelength $440 \mathrm{~nm}$. Content was denoted in terms of protein fluorescence.

\section{Assay of protease}

For protease assay, $0.2 \mathrm{~g}$ radicles was homogenized with borate buffer (0.2 M, pH 7.4) and centrifuged (11000 rpm, 15 $\mathrm{min}$ ). The supernatant was acetone-precipitated and resuspended in sodium phosphate buffer $(0.02 \mathrm{M}, \mathrm{pH} 6.4)$, and 1 $\mathrm{mL}$ of it was incubated with an equal volume of casein $(1 \%$, $\mathrm{w} / \mathrm{v}$ ) at $37^{\circ} \mathrm{C}$ for $3 \mathrm{~h}$ (Merheb et al. 2007). Then, $10 \%(\mathrm{w} / \mathrm{v})$ TCA was added to it to terminate the reaction, which was allowed to stand for $30 \mathrm{~min}$. The mixture was centrifuged at $11000 \mathrm{rpm}$ for $10 \mathrm{~min}$, and the collected supernatant was mixed with Folin Ciocalteu reagent $(1 \mathrm{~N})$ and sodium hydroxide $(0.2 \mathrm{~N})$, and incubated for $30 \mathrm{~min}$. Absorbance was read at $570 \mathrm{~nm}$, and activity was referred as units $\mathrm{g}^{-1}$ protein.

\section{Estimation of proteasome activity}

For proteasome assay, $0.2 \mathrm{~g}$ radicles was extracted with potassium phosphate buffer $(50 \mathrm{mM} \mathrm{pH} 7)$ comprising 2 $\mathrm{mM} \mathrm{MgCl}_{2}, 5 \%$ (v/v) glycerol, $5 \mathrm{mM}$ 2-mercaptoethanol and $10 \mathrm{mM}$ ATP, and then centrifuged $\left(11000 \mathrm{rpm}, 15 \mathrm{~min}, 4^{\circ} \mathrm{C}\right)$ (Yang et al. 2004). Supernatant obtained was incubated with $50 \mathrm{M}$ succinyl-Leu-Leu-Val-Tyr-7-amido-4-methylcoumarin (Suc-LLVY-AMC) prepared in potassium phosphate buffer $(80 \mathrm{mM}, \mathrm{pH} 7.0)$, at $37^{\circ} \mathrm{C}$ for $20 \mathrm{~min}$. Then, sodium acetate buffer ( $80 \mathrm{mM}, \mathrm{pH} 4.3$ ) was added to it, to inhibit the reaction. The AMC released was measured at $380 \mathrm{~nm}$ excitation and $440 \mathrm{~nm}$ emission and expressed in terms of units $\mathrm{mg}^{-1}$ protein.

\section{Assay of antioxidant enzymes}

The SOD (EC 1.15.1.1) was assayed by monitoring percent inhibition of pyrogallol auto-oxidation by the enzyme at $420 \mathrm{~nm}$ (Marklund and Marklund 1974). $2.74 \mathrm{~mL}$ of Tris$\mathrm{HCl}$ buffer $(50 \mathrm{mM}, \mathrm{pH} 8.2)$ comprising diethylenetriaminepentaacetic acid and EDTA, $1 \mathrm{mM}$ of each, was mixed with $0.2 \mathrm{~mL}$ of extracted enzyme. To initiate the reaction, $60 \mu \mathrm{L}$ of pyrogallol $(0.2 \mathrm{mM}$ prepared in $10 \mathrm{mM} \mathrm{HCl})$ was added to it, and change in absorbance was read at $420 \mathrm{~nm}$. Activity of SOD was denoted as units $\mathrm{min}^{-1} \mathrm{mg}^{-1}$ protein.

To monitor CAT (EC 1.11.1.6) activity, decomposition of $\mathrm{H}_{2} \mathrm{O}_{2}$ was measured by recording the fall in absorbance at $240 \mathrm{~nm}$ (Chance and Maehly 1955). In a test tube, $2.74 \mathrm{~mL}$ 
of potassium phosphate buffer $(37.5 \mathrm{mM}, \mathrm{pH} 6.8)$ and $60 \mu \mathrm{L}$ of enzyme were taken, and then a reaction was triggered by adding $200 \mu \mathrm{L}$ of $\mathrm{H}_{2} \mathrm{O}_{2}(60 \mathrm{mM})$. The change in absorbance was recorded for $5 \mathrm{~min}$ at an interval of $15 \mathrm{sec}$. Its activity was calculated using an extinction coefficient of $0.039 \mathrm{~mol}^{-1}$ $\mathrm{cm}^{-1}$ and denoted as nmol $\mathrm{min}^{-1} \mathrm{mg}^{-1}$ protein.

APX (EC 1.11.1.11) was estimated by monitoring the rate of ascorbate oxidation at $290 \mathrm{~nm}$ (Nakano and Asada 1981). In a test tube, $2.3 \mathrm{~mL}$ of $0.025 \mathrm{M}$ potassium phosphate buffer (pH 7.0), $500 \mu \mathrm{L}$ of $0.0025 \mathrm{M}$ ascorbic acid, $190 \mu \mathrm{L}$ of 0.001 $\mathrm{M}$ EDTA and $10 \mu \mathrm{L}$ of enzyme extract were added. Just after the addition of $10 \mu \mathrm{L}$ of $0.1 \mathrm{M} \mathrm{H}_{2} \mathrm{O}_{2}$ into the assay mixture, initial absorbance, and after 20 min of incubation, final absorbance was measured, at $290 \mathrm{~nm}$. APX activity was derived using extinction coefficient of $0.0028 \mathrm{~mol}^{-1} \mathrm{~cm}^{-1}$ and expressed as $\mathrm{mmol} \mathrm{min}{ }^{-1} \mathrm{mg}^{-1}$ protein.

\section{Isozyme analysis}

Electrophoretic analyses of SOD, CAT and APX were performed on native-polyacrylamide gels (10\%) using Trisglycine buffer ( $5 \mathrm{mM}, \mathrm{pH} 8.3$ ) (in case of APX, running buffer consists of $4 \mathrm{mM}$ ascorbate), at $4{ }^{\circ} \mathrm{C}$ for $2 \mathrm{~h}$ with a constant current of $20 \mathrm{~mA}$, using Mini-Protean tetra cell (BioRad, USA) (Chandrakar et al. 2016a). After a complete run, gels were imaged and analyzed using a Gel-Doc system (BioRad, USA).

To visualize the SOD, gels were incubated in the dark for $20 \mathrm{~min}$ in the $2.45 \mathrm{mM}$ NBT solution, and were then immersed in dipotassium hydrogen phosphate $(36 \mathrm{mM}, \mathrm{pH}$ 7.8) comprising riboflavin and TEMED, $28 \mu \mathrm{M}$ of each, until the gel turned blue except the region showing SOD activity (Chandrakar et al. 2016a). To stain CAT isozymes, the gels were incubated in $0.03 \%(\mathrm{v} / \mathrm{v}) \mathrm{H}_{2} \mathrm{O}_{2}$ solution for $10 \mathrm{~min}$. The gels were rinsed quickly in MW and stained in a solution consisting $1 \%(\mathrm{w} / \mathrm{v})$ each of potassium ferric chloride and ferricyanide. Soon after the green color appeared, the gels were washed with MW. Similarly, to detect APX, the gels were equilibrated with sodium phosphate buffer (50 $\mathrm{mM}, \mathrm{pH} 7)$ and ascorbate $(2 \mathrm{mM})$ for $30 \mathrm{~min}$. Then, the gels were incubated with sodium phosphate buffer $(50 \mathrm{mM}, \mathrm{pH}$ 7) comprising $4 \mathrm{mM}$ of each of ascorbate and $\mathrm{H}_{2} \mathrm{O}_{2}$ for 20 min. Finally, the gels were rinsed twice with $50 \mathrm{mM}$ sodium phosphate buffer ( $\mathrm{pH} 7)$ and stained in sodium phosphate buffer (50 mM, pH 7.8) consisting TEMED (28 mM) and NBT $(2.45 \mathrm{mM})$. The reaction was continued for $10-15 \mathrm{~min}$ and stopped by a brief wash with MW.

\section{Proline content}

To measure proline, $0.5 \mathrm{~g}$ radicles was extracted with $10 \mathrm{~mL}$ of sulfo-salicylic acid (3\%, w/v) and centrifuged (6000 rpm, $15 \mathrm{~min}$ ) (Bates et al. 1973). The supernatant (2 mL) was mixed with $2 \mathrm{~mL}$ each of ninhydrin reagent and glacial acetic acid. The mixture was incubated at $100^{\circ} \mathrm{C}$ for $60 \mathrm{~min}$, and cooled at room temperature. Then, $4 \mathrm{~mL}$ toluene was added and the chromophore containing toluene was aspirated out and its absorbance was recorded at $520 \mathrm{~nm}$ taking toluene as a blank. Its amount was expressed as $\mathrm{mg} \mathrm{g}^{-1} \mathrm{FM}$.

\section{Statistical analysis}

All the investigations were performed twice with five separate replications. The data obtained were subjected to oneway ANOVA, and the mean differences were compared by Duncun's multiple range tests using SPSS software (Ver. 16.0).

\section{Results}

The results demonstrated that the tested growth traits were significantly decreased (germination: $74 \%$, radicle length: $86 \%$, DM: $83 \%$ ) with As addition in Glycine max L., as compared to control, indicating a negative relationship between growth attributes and As (Tab. 1). However, the addition of DPI, EBL or Pro with As favored the growth traits by reducing (up to $86 \%$ ) the inhibitory impacts of stress in Glycine max L. (Tab. 1). Accumulated data revealed the growth-promoting nature of potential compounds. Additionally, amongst the tested treatments, Pro was found to be more effective in As-stress amelioration than DPI and EBL.

Radicles of Glycine max L. subjected to As $(100 \mu \mathrm{M})$ for

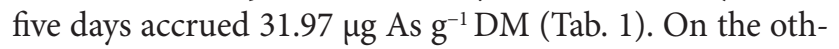
er hand, As accumulation in the radicles of Glycine max $\mathrm{L}$. grown in DPI-, EBL- or Pro-amended As-solution measured

Tab. 1. Comparative effects of diphenyleneiodonium (DPI), 24-epibrassinolide (EBL) and proline (Pro) in alleviation of arsenic (As)induced changes in germination percentage, radicle length, dry mass, arsenic content, electrolytes leakage and tissue viability in Glycine $\max \mathrm{L}$. Values presented are mean $\pm \mathrm{SE}$ of ten (for physiological parameters) or five (viability and arsenic content) different observations. Different letters indicate significant difference among treatments at $\mathrm{P}<0.05$.

\begin{tabular}{ccccccc}
\hline & Germination \% & Radicle length $(\mathrm{mm})$ & Dry mass $(\mathrm{g})$ & As content $\left(\mu \mathrm{g} \mathrm{g} \mathrm{g}^{-1} \mathrm{DM}\right)$ & Electrolyte leakage $(\%)$ & Viability $\left(\mathrm{A}_{520} \mathrm{~g}^{-1} \mathrm{FM}\right)$ \\
\hline Control & $100^{\mathrm{a}} \pm 0$ & $65^{\mathrm{c}} \pm 2$ & $0.11^{\mathrm{a}} \pm 0.01$ & - & $0.19^{\mathrm{c}} \pm 0.05$ & $1.28^{\mathrm{c}} \pm 0.008$ \\
DPI & $100^{\mathrm{a}} \pm 0$ & $70^{\mathrm{b}} \pm 2$ & $0.12^{\mathrm{a}} \pm 0.005$ & - & $0.18^{\mathrm{c}} \pm 0.002$ & $1.31^{\mathrm{b}} \pm 0.004$ \\
EBL & $100^{\mathrm{a}} \pm 0$ & $68^{\mathrm{b}} \pm 2$ & $0.12^{\mathrm{a}} \pm 0.005$ & - & $0.17^{\mathrm{c}} \pm 0.002$ & $1.34^{\mathrm{a}} \pm 0.005$ \\
Pro & $100^{\mathrm{a}} \pm 0$ & $76^{\mathrm{a}} \pm 2$ & $0.13^{\mathrm{a}} \pm 0.02$ & - & $0.16^{\mathrm{d}} \pm 0.004$ & $1.35^{\mathrm{a}} \pm 0.017$ \\
As & $26^{\mathrm{e}} \pm 3$ & $9^{\mathrm{f}} \pm 3$ & $0.02^{\mathrm{c}} \pm 0.01$ & $31.97 \pm 0.06$ & $2.91^{\mathrm{a}} \pm 0.04$ & $0.19^{\mathrm{f}} \pm 0.006$ \\
As+DPI & $58^{\mathrm{d} \pm 3}$ & $22^{\mathrm{e}} \pm 2$ & $0.03^{\mathrm{bc}} \pm 0.01$ & $26.25 \pm 0.04$ & $1.54^{\mathrm{b}} \pm 0.05$ & $0.22^{\mathrm{e}} \pm 0.001$ \\
As+EBL & $70^{\mathrm{c}} \pm 4$ & $22^{\mathrm{e}} \pm 2$ & $0.03^{\mathrm{b}} \pm 0.01$ & $23.02 \pm 0.03$ & $1.51^{\mathrm{b}} \pm 0.004$ & $0.24^{\mathrm{e}} \pm 0.005$ \\
As+Pro & $78^{\mathrm{b}} \pm 2$ & $28^{\mathrm{d}} \pm 2$ & $0.04^{\mathrm{b}} \pm 0.005$ & $21.87 \pm 0.04$ & $1.48^{\mathrm{b}} \pm 0.007$ & $0.29^{\mathrm{d}} \pm 0.008$ \\
\hline
\end{tabular}


only 26.25, 23.02 and $21.87 \mu \mathrm{g} \mathrm{As} \mathrm{g}^{-1} \mathrm{DM}$ respectively, which indicates that the above treatments permitted only a limited uptake of As in Glycine max L. The results revealed that Pro was the most effective treatment, allowing less As-uptake than the other two.

Exposure of Glycine max L. to As for five days caused enhanced accumulation of all the three $\operatorname{ROS}\left(\mathrm{O}_{2}{ }^{-}\right.$: $1340 \%$, 'OH: 239\%, $\mathrm{H}_{2} \mathrm{O}_{2}: 244 \%$ ), as compared to control (Tab. 2). However, exogenous application of DPI, EBL and Pro, separately, with As significantly lowered the amounts of ROS (Tab. 2). Gathered data suggested that Pro played a more prominent role than DPI and EBL in countering the deleterious impacts of As in Glycine max L.

A remarkable fall in the tetrazolium staining capacity/ viability of Glycine max L. exposed to As for five days was observed, as compared to control, revealing an inverse association between the two (Tab. 1). However, exogenous application of DPI, EBL and Pro, separately, with As was seen to maintain tissue viability to some extent (77-82\%), as compared to As-alone treated samples. However, Pro performed better than DPI and EBL in the amelioration of As-induced loss in tissue viability.

Compared to control, a significantly high rate of electrolyte leakage from radicles of Glycine max L. subjected to As for five days was discernible (Tab. 1). In contrast, exogenous addition of DPI, EBL or Pro with As resulted in statistically lower, 721, 737 and 753\% respectively, release of electrolytes. However, Pro was found to maintain membrane integrity better and in consequence allow lower leakage than DPI and EBL.

Arsenic-induced peroxidation of membrane lipid was measured in terms of both MDA and HNE, and found to be increased by 2674 and $2272 \%$ respectively as compared to controls (Tab. 2). However, in DPI-, EBL- and Pro-supplied As-subjected radicles, significantly low levels of MDA and HNE were measured (Tab. 2). In general, Pro exhibited a leading role in prevention of As-prompted lipid peroxidation in Glycine max L., greater than that of DPI and EBL.
Exposure of Glycine max L. to As for five days manifested a massive loss (91\%) in protein turnover, as compared to control. However, a considerably greater amount of it was measured in those subjected to As-solution amended with DPI, EBL or Pro (Tab. 2). The results suggested that Pro served as more effective treatment in compensation of protein level, than the DPI and EBL.

Activity measurements of both protease and proteasome in As-grown Glycine max L. revealed increases of 1390 and $204 \%$, respectively, as compared to their controls (Tab. 3). However, activities of both the enzymes were significantly less (protease: 994-1088\%, proteasome: 104-152\%) in those treated with DPI, EBL or Pro amended As solution, for five days. Moreover, Pro was seen to allow lower activities of these two enzymes than DPI and EBL in As-stressed Glycine max L.

Arsenic-impelled oxidation of protein was measured in terms of $\mathrm{PCO}, \mathrm{PrOOH}$ and MDA-/HNE-protein adducts, which were found to be raised considerably i.e. $381 \%, 200 \%$, $204 \%$ and $34 \%$ respectively, in As-treated five-day-old radicles as compared to control (Tabs. 3 and 4). In contrast, fewer accruals of these products were discernible in those samples grown in As solution amended with DPI, EBL or Pro (Tabs. 3 and 4). In general, Pro exhibited a leading role in the prevention of As-prompted protein oxidation in Glycine max L., more so than DPI and EBL.

Arsenic application manifested enhanced accumulation of both Pro (561\%) and total sugar (277\%) in Glycine max L., as compared to control (Tab. 3). The results witnessed that exogenous addition of DPI, EBL or Pro with As, caused further improvements in their accumulations. Maximum of both Pro (2.86 $\left.\mathrm{mg} \mathrm{g}^{-1} \mathrm{FM}\right)$ and total sugar (15.74 $\left.\mathrm{mg} \mathrm{g}^{-1} \mathrm{FM}\right)$ were measured in Pro-supplied As-grown radicles, proving it a better preventer of As-injury than DPI or EBL (Tab. 3).

Approximately 89 and 37\% more accumulations of both Amadori and Maillard reaction products were registered in the As-grown radicles than in the control (Tab. 4). However, their levels were comparatively less in those samples subjected

Tab. 2. Variations in the levels of superoxide anion, hydroxyl radical, hydrogen peroxide, malondialdehyde and 4-hydroxy-2-nonenal in Glycine max L. exposed to arsenic (As) alone or in combination with diphenyleneiodonium (DPI), 24-epibrassinolide (EBL) or proline (Pro). Given values are mean \pm SE of five separate observations. Different letters indicate significant difference at $\mathrm{P}<0.05$.

\begin{tabular}{cccccc}
\hline & $\begin{array}{c}\text { Superoxide anion } \\
\left(\mu \mathrm{mol} \mathrm{min} \mathrm{m}^{-1} \mathrm{~g}^{-1} \mathrm{FM}\right)\end{array}$ & $\begin{array}{c}\text { Hydroxyl radical } \\
\left(\mathrm{nmol} \mathrm{g} \mathrm{g}^{-1} \mathrm{FM}\right)\end{array}$ & $\begin{array}{c}\text { Hydrogen peroxide } \\
\left(\mu \mathrm{mol} \mathrm{g} \mathrm{g}^{-1} \mathrm{FM}\right)\end{array}$ & $\begin{array}{c}\text { Malondialdehyde } \\
\left(\mathrm{nmol} \mathrm{g}^{-1} \mathrm{FM}\right)\end{array}$ & $\begin{array}{c}\text { 4-Hydroxy-2-nonenal } \\
\left(\mathrm{mmol} \mathrm{g}^{-1} \mathrm{FM}\right)\end{array}$ \\
\hline Control & $1.68^{\mathrm{c}} \pm 0.79$ & $8.46^{\mathrm{e}} \pm 0.07$ & $0.36^{\mathrm{e}} \pm 0.007$ & $1.64^{\mathrm{e}} \pm 0.10$ & $0.11^{\mathrm{e}} \pm 0.007$ \\
DPI & $1.36^{\mathrm{c}} \pm 0.48$ & $4.34^{\mathrm{f}} \pm 0.52$ & $0.35^{\mathrm{e}} \pm 0.062$ & $1.62^{\mathrm{e}} \pm 0.43$ & $0.09^{\mathrm{e}} \pm 0.005$ \\
EBL & $1.10^{\mathrm{c}} \pm 0.48$ & $3.91^{\mathrm{g}} \pm 0.14$ & $0.27^{\mathrm{f}} \pm 0.026$ & $1.56^{\mathrm{e}} \pm 0.53$ & $0.08^{\mathrm{e}} \pm 0.002$ \\
Pro & $0.63^{\mathrm{c}} \pm 0.31$ & $3.67^{\mathrm{g}} \pm 0.17$ & $0.11^{\mathrm{g}} \pm 0.007$ & $1.57^{\mathrm{e}} \pm 0.32$ & $0.07^{\mathrm{e}} \pm 0.001$ \\
As & $24.20^{\mathrm{a}} \pm 0.48$ & $28.71^{\mathrm{a}} \pm 0.05$ & $1.24^{\mathrm{a}} \pm 0.009$ & $45.50^{\mathrm{a}} \pm 0.61$ & $2.61^{\mathrm{a}} \pm 0.03$ \\
As+DPI & $21.67^{\mathrm{a}} \pm 1.27$ & $17.52^{\mathrm{b}} \pm 0.07$ & $1.06^{\mathrm{b}} \pm 0.011$ & $37.80^{\mathrm{b}} \pm 0.10$ & $1.12^{\mathrm{b}} \pm 0.008$ \\
As+EBL & $19.88^{\mathrm{a}} \pm 6.5$ & $13.10^{\mathrm{c}} \pm 0.03$ & $1.00^{\mathrm{c}} \pm 0.038$ & $35.22^{\mathrm{c}} \pm 0.04$ & $1.05^{\mathrm{c}} \pm 0.001$ \\
As+Pro & $10.31^{\mathrm{b}} \pm 3.37$ & $10.62^{\mathrm{d}} \pm 0.12$ & $0.94^{\mathrm{d}} \pm 0.004$ & $34.11^{\mathrm{d}} \pm 0.05$ & $1.00^{\mathrm{d} \pm 0.001}$ \\
\hline
\end{tabular}


Tab. 3. Levels of proteins, protein hydroperoxides, protease, proteasome, sugar and proline in Glycine max L. exposed to arsenic (As) alone or in combination with diphenyleneiodonium (DPI), 24-epibrassinolide (EBL) or proline (Pro). Data presented are mean \pm SE of five individual replicates. Different letters indicate significant difference among treatments at $\mathrm{P}<0.05$.

\begin{tabular}{ccccccc}
\hline & $\begin{array}{c}\text { Proteins } \\
\left(\mathrm{mg} \mathrm{g}^{-1} \mathrm{FM}\right)\end{array}$ & $\begin{array}{c}\text { Protein hydroperoxides } \\
\left(\mathrm{mmol} \mathrm{mg}^{-1} \text { protein }\right)\end{array}$ & $\begin{array}{c}\text { Protease } \\
\left(\text { Units g }{ }^{-1} \text { protein }\right)\end{array}$ & $\begin{array}{c}\text { Proteasome } \\
\left(\text { Units }^{-1} \text { protein }\right)\end{array}$ & $\begin{array}{c}\text { Sugar } \\
\left(\mathrm{mg} \mathrm{g}^{-1} \mathrm{FM}\right)\end{array}$ & $\begin{array}{c}\text { Proline } \\
\left(\mathrm{mg} \mathrm{g}^{-1} \mathrm{FM}\right)\end{array}$ \\
\hline Control & $8.57^{\mathrm{d}} \pm 0.77$ & $1.21^{\mathrm{c}} \pm 0.04$ & $0.053^{\mathrm{e}} \pm 0.002$ & $0.21^{\mathrm{e}} \pm 0.03$ & $3.1^{\mathrm{g}} \pm 0.27$ & $0.31^{\mathrm{d}} \pm 0.006$ \\
DPI & $17.66^{\mathrm{c}} \pm 0.98$ & $0.89^{\mathrm{d}} \pm 0.06$ & $0.049^{\mathrm{ef}} \pm 0.007$ & $0.17^{\mathrm{f}} \pm 0.008$ & $4.04^{\mathrm{f}} \pm 0.09$ & $0.28^{\mathrm{d}} \pm 0.01$ \\
EBL & $20.38^{\mathrm{b}} \pm 0.59$ & $0.77^{\mathrm{e}} \pm 0.01$ & $0.047^{\mathrm{ef}} \pm 0.002$ & $0.16^{\mathrm{f}} \pm 0.01$ & $4.91^{\mathrm{e}} \pm 0.11$ & $0.29^{\mathrm{d}} \pm 0.005$ \\
Pro & $27.17^{\mathrm{a}} \pm 0.32$ & $0.73^{\mathrm{e}} \pm 0.02$ & $0.042^{\mathrm{f}} \pm 0.001$ & $0.15^{\mathrm{f}} \pm 0.004$ & $5.47^{\mathrm{d}} \pm 0.11$ & $0.29^{\mathrm{d}} \pm 0.005$ \\
As & $0.69^{\mathrm{h}} \pm 0.23$ & $4.23^{\mathrm{a}} \pm 0.07$ & $0.79^{\mathrm{a}} \pm 0.007$ & $0.64^{\mathrm{a}} \pm 0.02$ & $11.71^{\mathrm{c} \pm 0.72}$ & $2.05^{\mathrm{c}} \pm 0.19$ \\
As+DPI & $3.22^{\mathrm{g}} \pm 0.02$ & $1.85^{\mathrm{b}} \pm 0.12$ & $0.63^{\mathrm{b}} \pm 0.002$ & $0.53^{\mathrm{b}} \pm 0.01$ & $12.03^{\mathrm{c}} \pm 0.04$ & $2.65^{\mathrm{b}} \pm 0.11$ \\
As+EBL & $6.42^{\mathrm{f}} \pm 0.07$ & $1.43^{\mathrm{c}} \pm 0.006$ & $0.60^{\mathrm{c}} \pm 0.003$ & $0.47^{\mathrm{c}} \pm 0.01$ & $15.13^{\mathrm{b}} \pm 0.07$ & $2.72^{\mathrm{ab}} \pm 0.04$ \\
As+Pro & $8.01^{\mathrm{e}} \pm 0.15$ & $1.35^{\mathrm{c}} \pm 0.02$ & $0.58^{\mathrm{d}} \pm 0.007$ & $0.43^{\mathrm{d}} \pm 0.01$ & $15.74^{\mathrm{a}} \pm 0.06$ & $2.86^{\mathrm{a}} \pm 0.09$ \\
\hline
\end{tabular}

Tab. 4. Amendments in the levels of Amadori and Maillard reaction products, protein carbonyls and malondialdehyde (MDA)-/ 4-hydroxy2-nonenal (HNE)-protein adducts in Glycine max L. subjected to arsenic (As) alone or in combination with diphenyleneiodonium (DPI), 24-epibrassinolide (EBL) or proline (Pro) for five days. Observations are mean \pm SE of five independent replications. Different letters indicate significant difference among treatments at $\mathrm{P}<0.05$.

\begin{tabular}{|c|c|c|c|c|c|}
\hline & $\begin{array}{c}\text { Amadori products } \\
(\Delta \mathrm{OD})\end{array}$ & $\begin{array}{l}\text { Maillard products } \\
\text { (protein fluorescence) }\end{array}$ & $\begin{array}{l}\text { Protein carbonyls } \\
\left.\text { ( } \mu \text { mol mg }{ }^{-1} \text { protein }\right)\end{array}$ & $\begin{array}{l}\text { MDA-protein adduct } \\
\text { (UF } \mathrm{mg}^{-1} \text { protein) }\end{array}$ & $\begin{array}{l}\text { HNE-protein adduct } \\
\text { (UF mg-1 protein) }\end{array}$ \\
\hline Control & $0.011^{\mathrm{e}} \pm 0.001$ & $110.86^{\mathrm{e}} \pm 0.56$ & $54.20^{\mathrm{e}} \pm 0.17$ & $155.83^{\mathrm{e}} \pm 0.53$ & $379.28^{\mathrm{e}} \pm 0.73$ \\
\hline DPI & $0.008^{f} \pm 0.00001$ & $102.13^{\mathrm{f}} \pm 0.75$ & $52.69^{\mathrm{fg}} \pm 0.68$ & $153.74^{\mathrm{e}} \pm 1.11$ & $271.12^{\mathrm{f}} \pm 1.45$ \\
\hline EBL & $0.007^{f} \pm 0.00001$ & $97.42^{\mathrm{g}} \pm 0.34$ & $50.63^{\mathrm{ef}} \pm 0.39$ & $151.22^{\mathrm{e}} \pm 0.38$ & $251.96^{\mathrm{g}} \pm 0.32$ \\
\hline Pro & $0.004^{\mathrm{g}} \pm 0.0005$ & $94.43^{\mathrm{h}} \pm 0.29$ & $49.21^{g} \pm 0.47$ & $136.38^{\mathrm{g}} \pm 0.06$ & $240.24^{\mathrm{h}} \pm 0.57$ \\
\hline As & $0.100^{\mathrm{a}} \pm 0.002$ & $152.11^{\mathrm{a}} \pm 0.62$ & $261.24^{\mathrm{a}} \pm 1.40$ & $474.10^{\mathrm{a}} \pm 2.47$ & $510.24^{\mathrm{a}} \pm 0.90$ \\
\hline As+DPI & $0.082^{b} \pm 0.0007$ & $147.25^{\mathrm{b}} \pm 0.35$ & $145.49^{\mathrm{b}} \pm 4.56$ & $344.55^{\mathrm{b}} \pm 0.72$ & $475.39^{\mathrm{b}} \pm 1.23$ \\
\hline $\mathrm{As}+\mathrm{EBL}$ & $0.075^{\mathrm{c}} \pm 0.0001$ & $142.70^{c} \pm 0.46$ & $98.11^{c} \pm 0.83$ & $341.26^{\mathrm{c}} \pm 1.13$ & $462.62^{\mathrm{c}} \pm 1.21$ \\
\hline As+Pro & $0.062^{\mathrm{d}} \pm 0.0004$ & $137.38^{\mathrm{d}} \pm 0.43$ & $90.20^{\mathrm{d}} \pm 0.67$ & $246.45^{\mathrm{d}} \pm 1.48$ & $391.47^{\mathrm{d}} \pm 0.65$ \\
\hline
\end{tabular}

to DPI-, EBL- or Pro-supplied As solutions. In this study, Pro exhibited a leading role in compensating As-prompted protein glycation in Glycine max L., more so than DPI and EBL.

Treatment of As significantly decreased the activities of SOD (48\%), CAT (75\%) and APX (69\%) in the five-day-old radicles, but exogenous addition of DPI, EBL or Pro alleviated this decline by up to 67\%, under As-stress (Figs. 1-3). However, activities of these were higher $(63,51$ and $36 \%$ respectively) in Pro added As-subjected radicles, than the DPI or EBL added As-grown (Figs. 1-3).

Isozyme analysis of SOD unveiled a total of six isoforms in response to As and/ or DPI, EBL and Pro. Exposure to As revealed only one band but isozymes-II-IV were restored when DPI, EBL or Pro was added with As (Fig. 1). Additionally, intensities of isoforms-II-IV were higher in presence of Pro as compared to that of the DPI and EBL.

In gel activity analysis of CAT in Glycine max L. unveiled presence of at least three isoforms in control, DPI, EBL or Pro-treated samples (Fig. 2). On the other hand, reductions in both intensities and number of bands were observed in As-treated samples (Fig. 2). Band intensity was higher in Pro-supplied As-grown samples than in DPI- or EBL added As-subjected samples.

Staining of APX identified four isoforms of it in As and/ or DPI-, EBL- and Pro-subjected samples (Fig. 3). Out of these, isoform-I is common in all the treatments. Addition-

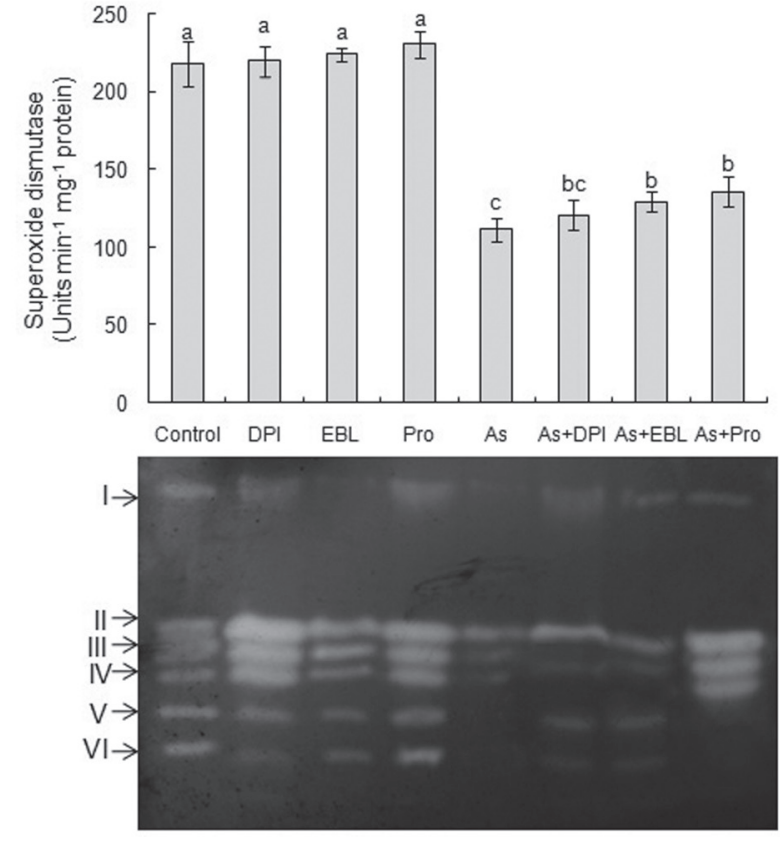

Fig. 1. Spectrophotometric activity (upper part) and isoenzymic pattern (lower part) of superoxide dismutase in Glycine max L. grown in various experimental solutions of arsenic (As), diphenyleneiodonium (DPI), 24-epibrassinolide (EBL) or proline (Pro) for five days. Bars presented in the graphs are mean \pm SE of five separate observations. Different letters indicate significant differences among treatments at $\mathrm{P}<0.05$. 
ally, two new isoforms (II and III) were induced exclusively in samples treated with EBL and Pro only. More bands appeared in Pro + As-treated samples than in the DPI- or EBLamended As-grown samples.

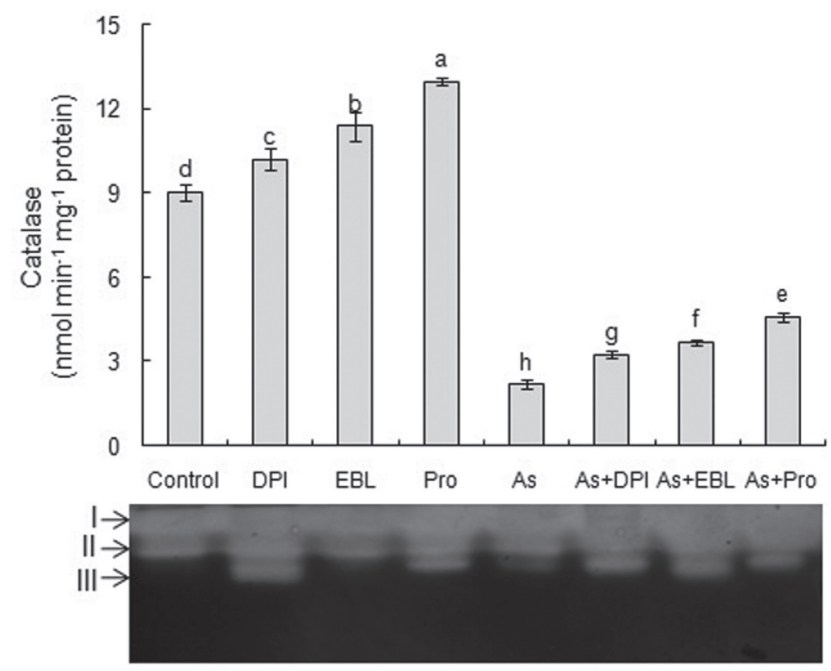

Fig. 2. Activity of catalase, spectrophotometric assay (upper part) and isoenzymic pattern (lower part) of Glycine max L. exposed to various treatments of arsenic (As), diphenyleneiodonium (DPI), 24-epibrassinolide (EBL) or proline (Pro). Each bar is mean $\pm \mathrm{SE}$ of five distinct observations. Different letters indicate significant differences at $\mathrm{P}<0.05$.

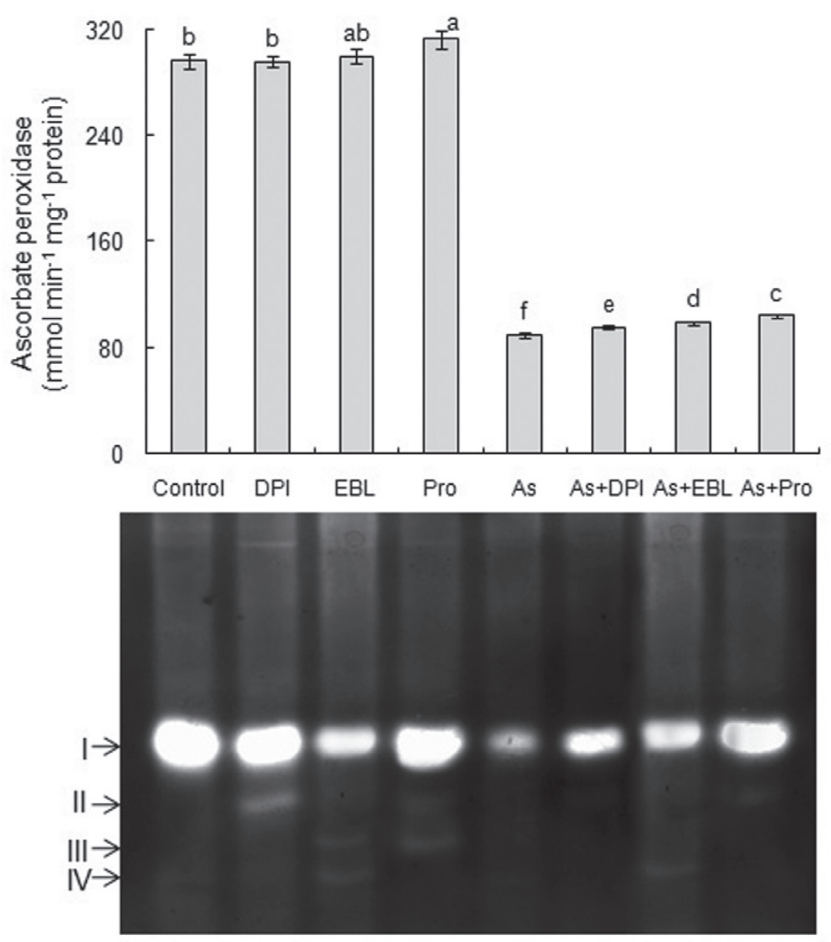

Fig. 3. Quantitative estimation (upper part) and isoenzymic pattern (lower part) of ascorbate peroxidase in Glycine max L. subjected to different experimental solutions of arsenic (As), diphenyleneiodonium (DPI), 24-epibrassinolide (EBL) or proline (Pro). Each bar is mean $\pm \mathrm{SE}$ of five distinct observations. Different letters indicate significant differences at $\mathrm{P}<0.05$.

\section{Discussion}

Arsenic is a non-essential metalloid, ubiquitously present in the natural environment. The presence of it in the soil above the permissible limit adversely affects plant growth, development and productivity. A recent report of ours revealed that As-treatment leads to oxidative stress in Glycine max L. (Chandrakar et al. 2016a). However, the current study was aimedat evaluating the comparative efficacy of DPI, EBL and Pro in the amelioration of As-promoted oxidative injuries in Glycine max L. The results showed that the exogenous application of DPI, EBL and Pro enabled Glycine max L. to cope with As-induced oxidative stress, although in differing rates, consequentially improved growth traits (germination percentage, RL and DM), viability, levels of protein, sugar, Pro and antioxidant enzymes, and reduced electrolyte leakage, ROS, MDA, HNE, PCO, PrOOH, Amadori and Maillard reaction products, MDA-/ HNE-protein adducts, and activities of both protease and proteasome. However, Pro was found to be more effective than DPI and EBL in improving As-stress tolerance in Glycine max L.

Experimental results proved that Glycine max L. subjected to As for five days exhibited considerable reductions in germination percentage (74\%), RL (86\%) and DM (83\%), as compared to controls (Tab. 1). This reduced germination and inhibited growth in response to As might be related with the lower mitotic activity that decreased the rate of cell division, expansion and elongation of newly formed cells (Chandrakar et al. 2016a). Additionally, inside the cell, As causes disruption in the cellular energy flow by replacing the phosphate of the ATP molecule. Hence, reduced germination and growth responses are possibly due to the detrimental effects of As on the cellular functioning of the plants, where most of the available energy is consumed in the formation of stresslinked essentials like phytochelatins, anti-oxides, etc. (Farooq et al. 2015). Similarly, reduced DM is possibly an outcome of As-promoted increase in membrane permeability and thereby loss of electrolytes and other important constituents of the cell, essentially required for growth and development processes. These results are consistent with the findings of Anjum et al. (2016) and Begum et al. (2016) in As-exposed Zea mays L. and Oryza sativa L. respectively. However, exogenous addition of DPI, EBL or Pro, particularly Pro, with As, remarkably improved the growth traits of Glycine max L., probably by protecting the structures of plasma membranes and cell walls, under stress conditions. DPI, EBL and Pro are have been recorded in publications as enhancing seed germination and root/ shoot growth in different plants under various abiotic stresses (Hayat et al. 2012, Ye et al. 2012, Agami 2014, Chandrakar et al. 2017a). Inhibited growth responses coincided well with enhanced accumulation of As in the Glycine max L. radicles. Accrual of As inside the cells might be the result of damaged cell membranes, alterations in the cell wall structures and/ or rapid influx of it through transporters of the exposed cells (Singh et al. 2015). A similar result was recently recorded by Chandrakar et al. (2017b). On the other hand, exogenous application of DPI, EBL or Pro with 
As revealed lesser accumulation of As, possibly by preventing entry of it via the maintenance of the structures of the plasma membranes and cell walls and the modification of As-transporters. Inside the cell, As readily binds with sulfhydryl groups of both proteins and enzymes, consequently inhibiting cellular metabolism, which finally results in cell death (Farooq et al. 2015). Results of TTC test revealed a notable fall in the vitality of As-stressed Glycine max L. tissue, which was in agreement with the report of Kaur et al. (2012) in Phaseolus aureus L. On the other hand, in protective treatments, exogenous DPI, EBL or Pro, more precisely Pro, maintained the vitality of Glycine max L. radicles, up to a large extent, even under As-stress. DPI, EBL and Pro decreased As accrual, which resulted in a better antioxidant system, hence lesser oxidative stress and increased viability. This condition might help Glycine max L. to survive under As-stress. Exogenous EBL and Pro were shown to increase the viability of the roots in Lycopersicon esculentum Mill. and Cicer arietinum L. exposed to extreme heat (Kaushal et al. 2011, Khan et al. 2014).

Exposure to As raised accumulation of all the three ROS $\left(\mathrm{O}_{2}{ }^{\cdot{ }^{-}}\right.$: $1340 \%$, $\left.\mathrm{OH}: 239 \%, \mathrm{H}_{2} \mathrm{O}_{2}: 244 \%\right)$ in Glycine max L., and was accompanied with an enhanced rate of electrolyte leakage (Tab. 1). In regard, Singh et al. (2015) demonstrated that interaction between As and intracellular components may result in overproduction of ROS in stressed cells. Further, being an oxidizing agent, ROS disturbs membrane integrity drastically, consequentially enhancing the leakage of cellular constituents. A similar change in free radical generation and related electrolyte leakage under As-stress has been observed in Oryza sativa L. (Begum et al. 2016) and Zea mays L. (Anjum et al. 2016). The results of the present study indicate that the As-induced oxidative damage in Glycine max L. was compensated for remarkably by exogenous DPI, EBL or Pro, by limiting ROS production and electrolyte release. It has been suggested that DPI directly scavenges ROS or decelerates the ROS generation process via inhibiting $\mathrm{O}_{2}{ }^{-}{ }^{-}$synthase enzyme (Ye et al. 2012). Similarly, EBL and Pro provide tolerance to oxidative stress either by accumulating endogenous osmolytes or activating antioxidant defense mechanism or both in the stressed tissues (Agami 2014, Shu et al. 2015). In this manner, DPI, EBL and Pro, particularly Pro, lower the ROS in As-stressed tissues. This is in accordance with the reports of Ye et al. (2012), Shu et al. (2015), Singh et al. (2015) and Chandrakar et al. (2017a) under different abiotic stresses. Arsenic-impelled alterations in lipid moieties of Glycine max L. were analyzed by measuring contents of both MDA and HNE. Accumulated data showed that the contents of MDA and HNE, the chief indicators in the monitorin gof oxidative injury, rose considerably in the As-exposed Glycine max L. (Tab. 2), which might be attributed to the enhanced accumulation of ROS, known to cause membrane lipid oxidation (Parkhey et al. 2014b). Increased MDA was also measured in As-exposed Oryza tenuiflorum L. and Zea mays L. by Siddiqui et al. (2015) and Anjum et al. (2016) respectively. The detrimental impacts of As in Glycine max L., however, was attenuated substantially after the addition of DPI, EBL or Pro; moreover, among the three treatments, Pro was recognized to be the most effective against As-stress. Since Pro acts as a free radical scavenger and membrane stabilizer, it protects the lipid fractions from being oxidized, and thereby there is less accumulation of lipid peroxidized products (Siddiqui et al. 2015, Chandrakar et al. 2017b). Arsenic-prompted increase in ROS accumulation led oxidation of proteins and was analyzed by measuring protein and its oxidized products ( $\mathrm{PCO}$ and $\mathrm{PrOOH}) /$ aldehydic adducts (MDA- and HNE-protein adducts). The results revealed that on exposure to As, there was a fall in protein content with concomitant increase in both PCO and PrOOH, compared to the control. Decreased protein with increased PCO was recently reported in As-exposed seedlings of Zea mays L. by Mallick et al. (2013). However, there is nothing in the literature concerning the measurement of $\mathrm{PrOOH}$, and MDA- and HNE-protein adducts in response to any metal/metalloid-toxicity in plants. The detrimental impacts of As in Glycine max L. were attenuated substantially after the exogenous addition of DPI, EBL and Pro, hence protein content was increased substantially and the levels of $\mathrm{PCO}, \mathrm{PrOOH}$, and MDA- and HNE-protein adducts were lowered (Tabs. 3 and 4). However, Pro was recognized to be more effective than DPI and EBL against As-stress; it is well known to stabilize protein structures and conformations (Wu et al. 2015). Similarly, a massive rise in both Amadori and Maillard reaction products was observed in As-subjected Glycine max L. In this regard, Mostofa (2015) demonstrated that increased accumulation of glycation end products led to oxidative injury in Oryza sativa L. upon Cd exposure. However, treatment with DPI, EBL or Pro decreased these products to a certain degree, and proved their potentialities in As-stress alleviation (Tab. 4). These compounds decrease ROS accumulation and stabilize protein structure, and thereby enhances As-stress resistance in Glycine max L.

Compatible osmolytes such as Pro, sugar, etc., regulate the osmotic potential of cells exposed to abiotic stresses (Yadu et al. 2016, Chandrakar et al. 2017a). The results revealed that in response to As, accumulation of endogenous Pro and sugar were increased as compared with their respective controls. Our data are in agreement with those of Jha and Dubey (2005) and Anjum et al. (2016). However, accumulations of these osmolytes were further increased by the application of DPI, EBL or Pro with As. At an increased level, endogenous Pro directly scavenges 'OH radicals and lowers As accumulation, hence providing protection against As-toxicity. Likewise, enhanced sugar accrual may contribute to the osmotic balance in the cell, and provide sufficient storage reserves for faster recovery of plants under stressful conditions (Jha and Dubey 2005).

Exposure to As not only leads to protein oxidation, but also to accrual of damaged/oxidized proteins. If not eliminated readily, such proteins may form large aggregates due to covalent cross-linking, that may lead to cell death (Karmous et al. 2014). Both protease and proteasome are involved in the removal of such aggregated and damaged proteins from the cell (Jin et al. 2016). The results revealed that 
activities of both protease and proteasome increased in the presence of As more than in their respective controls, and this is well supported by the report of Jin et al. (2016). Improved protease and proteasome could be the consequence of an increased need to remove oxidatively damaged proteins from the cell (Karmous et al. 2014). Data from the current study showed that upon supplementation of DPI, EBL or Pro along with As protease and proteasome activity decreased, as they lowered the formation of protein oxidized products. To maintain ROS homeostasis, plants possess an enzymatic defense system, which includes SOD, CAT, APX, etc. (Yadu et al. 2017). Exposure to As caused a decline in the activities of the above enzymes in Glycine max L., which is consistent with the results of Kaur et al. (2012). Hence, antioxidant system might not be properly stimulated to attain the desired regulation over ROS accumulation, which in turn contributes to greater oxidative stress in As-exposed Glycine max L. Further, DPI, EBL or Pro supplementation to As activates the antioxidant system, hence confirms their protective roles in mitigating As-induced deleterious impacts in Glycine max L. Similar change in the activities of antioxidant enzymes in relation to exogenous DPI, EBL or Pro into different abiotically stressed plants has previously been documented by Jiang and Zhang (2002), Agami (2014) and Fariduddin et al. (2015).

\section{References}

Agami, R. A., 2014: Applications of ascorbic acid or proline increase resistance to salt stress in barley seedlings. Biologia Plantarum 58, 341-347.

Anjum, S. A., Tanveer, M., Hussain, S., Shahzad, B., Ashraf, U., Fahad, S., Hassan, W., Jan, S., Khan, I., Saleem, M. F., Bajwa, A. A., Wang, L., Mahmood, A., Samad, R. A., Tung, S. A., 2016: Osmoregulation and antioxidant production in maize under combined cadmium and arsenic stress. Environmental Science and Pollution Research 23, 11864-11875.

Bates, L. S., Walrow, R. P., Teare, I. D., 1973: Rapid determination of free proline for water stress studies. Plant and Soil 39, 205-208.

Begum, M. C., Islam, M. S., Islam, M., Amin, R., Parvez, M. S., Kabir, A. H., 2016: Biochemical and molecular responses underlying differential arsenic tolerance in rice (Oryza sativa L.). Plant Physiology and Biochemistry 104, 266-277.

Blum, A., Ebercon, A., 1981: Cell membrane stability as a measure of drought and heat tolerance in wheat. Crop Science 21, 43-47.

Bradford, M. M., 1976: A rapid and sensitive method for the quantitation of microgram quantities of protein utilizing the principle of protein-dye binding. Analytical Biochemistry 72, 248-257.

Chairpotto, E., Scavazza, A., Leonarduzzi, G., Camandola, S., Biasi, F., Teggia, P. M., Garavogilia, M., Robecchi, A., Roncari, A., Poli, G., 1997: Oxidative damage and transforming growth factor expression in pretumorial and tumoral lesions of human intestine. Free Radical Biology and Medicine 22, 889-894.

Chance, M., Maehly, A. C., 1955: Assay of catalases and peroxidases. Methods in Enzymology 2, 764-817.

Chandrakar, V., Dubey, A., Keshavkant, S., 2016a: Modulation of antioxidant enzymes by salicylic acid in arsenic exposed Glycine $\max$ L. Journal of Soil Science and Plant Nutrition 16, 662-676.
Exogenous application of DPI, EBL or Pro was effective in alleviating the detrimental effects to Glycine $\max \mathrm{L}$. of Asstress. The beneficial effects of DPI, EBL and Pro may be attributed to improvement in germination, growth, viability and antioxidant defense system to alleviate the ROS-induced membrane damage and increased lipid and protein oxidized products. Thus, exogenous application of DPI, EBL and Pro provides tolerance to As-stress in Glycine max L. Moreover, Pro performed better in reducing As-induced oxidative injury than DPI or EBL. The current approach could be useful in unravelling the mechanism(s) behind amelioration of As-induced oxidative injury in plants.

\section{Acknowledgements}

The authors would like to thank the Department of Science \& Technology, New Delhi, for awarding an INSPIRE fellowship (No. DST/INSPIRE Fellowship/2013/791, dated 23.01.2013) to Vibhuti Chandrakar. The authors are also grateful to the Department of Science \& Technology, New Delhi and the Chhattisgarh Council of Science and Technology for financial support through DST-FIST scheme (Sanction No. 2384/IFD/2014-15, dated 31.07.2014) to this School, and project (Sanction No. 2741/CCOST/MRP/2015, dated 24/03/2015) respectively, sanctioned to the S. Keshavkant.

Chandrakar, V., Naithani, S. C., Keshavkant, S., 2016b: Arsenicinduced metabolic disturbances and their mitigation mechanisms in crop plants: A review. Biologia 71, 367-377.

Chandrakar, V., Yadu, B., Meena, R. K, Dubey, A., Keshavkant, S., 2017a: Arsenic-induced genotoxic responses and their amelioration by diphenylene iodonium, 24-epibrassinolide and proline in Glycine max L. Plant Physiology and Biochemistry $112,74-86$.

Chandrakar, V., Parkhey, S., Dubey, A., Keshavkant, S., 2017b: Modulation in arsenic-induced lipid catabolism in Glycine $\max \mathrm{L}$. using proline, 24-epibrassinolide and diphenylene iodonium. Biologia 72, 292-299.

Fariduddin, Q., Ahmed, M., Mir, B. A., Yusuf, M., Khan, T. A., 2015: 24-Epibrassinolide mitigates the adverse effects of manganese induced toxicity through improved antioxidant system and photosynthetic attributes in Brassica juncea. Environmental Science and Pollution Research 22, 11349-11359.

Farooq, M. A., Gill, R. A., Ali, B., Wang, J., Islam, F., Ali, S., Zhou, W., 2015: Oxidative injury and antioxidant enzymes regulation in arsenic-exposed seedlings of four Brassica napus L. cultivars. Environmental Science and Pollution Research 22, 10699-10712.

Gay, C., Collins, J., Gebicki, J. M., 1999: Hydroperoxide assay with the ferric-xylenol orange complex. Analytical Biochemistry 273, 149-155.

Hayat, S., Maheshwari, P., Wani, A. S., Irfan, M., Alyemeni, M. N., Ahmad, A., 2012: Comparative effect of 28 homobrassinolide and salicylic acid in the amelioration of $\mathrm{NaCl}$ stress in Brassica juncea L. Plant Physiology and Biochemistry 53, 61-68.

Jha, A. B., Dubey, R. S., 2005: Effect of arsenic on behaviour of enzymes of sugar metabolism in germinating rice seeds. Acta Physiologiae Plantarum 27, 341-347.

Jiang, M., Zhang, J., 2002: Water stress-induced abscisic acid accumulation triggers the increased generation of reactive oxy- 
gen species and up-regulates the activities of antioxidant enzymes in maize leaves. Journal of Experimental Botany 53, 2401-2410.

Jin, H., Xu, M., Chen, H., Zhang, S., Han, X., Tang, Z., Sun, R., 2016: Comparative proteomic analysis of differentially expressed proteins in Amaranthus hybridus L. roots under cadmium stress. Water Air and Soil Pollution 227, 220-232.

Karmous, Q. I., Chaoui, A., Jaouani, K., Sheehan, D., Ferjani, E. E., Scoccianti, V., Crinelli, R., 2014: Role of the ubiquitin-proteasome pathway and some peptidases during seed germination and copper stress in bean cotyledons. Plant Physiology and Biochemistry 30, 1-9.

Kaushal, N., Gupta, K., Bhandhari, K., Kumar, S., Thakur, P., Nayyar, H., 2011: Proline induces heat tolerance in chickpea (Cicer arietinum L.) plants by protecting vital enzymes of carbon and antioxidative metabolism. Physiology and Molecular Biology of Plants 17, 203-213.

Khan, A. R., Cheng, Z., Ghazanfar, B., Khan, M. A., Yongxing, Z., 2014: Acetyl salicylic acid and 24-epibrassinolide enhance root activity and improve root morphological features in tomato plants under heat stress. Acta Agriculturae Scandinavica, Section B-Soil and Plant Science 64, 304-311.

Kaur, S., Singh, H. P., Batish, D. R., Negi, A., Mahajan, P., Rana, S., Kohli, R. K., 2012: Arsenic (As) inhibits radicle emergence and elongation in Phaseolus aureus by altering starch-metabolizing enzymes vis-à-vis disruption of oxidative metabolism. Biological Trace Element Research 146, 360-368.

Lakon, G., 1949: The topographical tetrazolium method for determining the germinating capacity of seeds. Plant Physiology 24, 389-394.

Levine, R. L., Williams, J. A., Stadtman, E. R., Shacter, E., 1994: Carbonyl assay for determination of oxidatively modified proteins. Methods in Enzymology 233, 346-357.

Mallick, S., Kumar, N., Singh, A. P., Sinam, G., Yadav, R. N., Sinha, S., 2013: Role of sulfate in detoxification of arsenate-induced toxicity in Zea mays L. (SRHM 445): nutrient status and antioxidants. Journal of Plant Interactions 8, 140-154.

Marklund, S., Marklund, G. 1974: Involvement of the superoxide anion radical in the autoxidation of pyrogallol and a convenient assay for superoxide dismutase. European Journal of Biochemistry 47, 469-474.

Merheb, C. W., Cabral, H., Gomes, E., Da-silva, R., 2007: Partial characterization of protease from a thermophilic fungus, its hydrolytic activity on bovine casein. Food Chemistry 104, 127-131.

Mostofa, M. G., 2015: Physiological and biochemical mechanisms associated with trehalose-induced copper-stress tolerance in rice. Scientific Reports 5, 1-16.

Murthy, U. M., Sun, W. Q., 2000: Protein modification by Amadori and Maillard reactions during seed storage: roles of sugar hydrolysis and lipid peroxidation. Journal of Experimental Botany 51, 1221-1228.

Nakano, Y., Asada, K., 1981: Hydrogen peroxide is scavenged by spinach chloroplasts. Plant Cell Physiology 22, 867-880.
Nikolic, N., Borišev, M., Pajević, S., Župunski, M., Topić, M., Arsenov, D., 2014: Responses of wheat (Triticum aestivum L.) and maize (Zea mays L.) plants to cadmium toxicity in relation to magnesium nutrition. Acta Botanica Croatica 73, 359-373.

Parkhey, S., Naithani, S. C., Keshavkant, S., 2014a: Protein metabolism during natural ageing in desiccating recalcitrant seeds of Shorea robusta. Acta Physiologiae Plantarum 36, 1649-1659.

Parkhey, S., Tandan, M., Keshavkant, S., 2014b: Salicylic acid and acquisition of desiccation tolerance in Pisum sativum seeds. Biotechnology 13, 217-225.

Ray, S., Roy, K., Sengupta, C., 2007: Evaluation of protective effect of water extract of Spirulina plantensis (blue green algae) on cisplatin-induced lipid peroxidation. Indian Journal of Pharmaceutical Science 3, 378-382.

Sangeetha, P., Das, V. N., Koratker, R., Suryaprabha, P., 1990: Increase in free radical generation and lipid peroxidation following chemotherapy in patients with cancer. Free Radical Biology and Medicine 8, 15-19.

Shu, H., Ni, W., Guo, S., Gong, Y., Shen, X., Zhang, X., Xu, P., Guo, Q., 2015: Root-applied brassinolide can alleviate the $\mathrm{NaCl}$ injuries on cotton. Acta Physiologiae Plantarum 37, 75-86.

Siddiqui, F., Tandon, P. K., Srivastava, S., 2015: Analysis of arsenic induced physiological and biochemical responses in a medicinal plant, Withania somnifera. Physiology and Molecular Biology of Plants 21, 61-69.

Singh, M., Singh, V. P., Dubey, G., Prasad, S. M., 2015: Exogenous proline application ameliorates toxic effects of arsenate in Solanum melongena L. seedlings. Ecotoxicology and Environmental Safety 117, 164-173.

Spiro, R. G., 1966: Analysis of sugars found in glycoproteins. Methods in Enzymology 8, 3-52.

Velikova, V., Yordanov, I., Edreva, A., 2000: Oxidative stress and some antioxidant systems in acid rain treated bean plants: protective role of exogenous polyamines. Plant Science 151, 59-66.

Wu, X. X., Ding, H. D., Chen, J. L., Zhu, Z. W., Zha, D. S., 2015: Amelioration of oxidative damage in Solanum melongena seedlings by 24 -epibrassinolide during chilling stress recovery. Biologia Plantarum 59, 350-356.

Yadu, B., Chandrakar, V., Keshavkant, S., 2016: Responses of plants towards fluoride: An overview of oxidative stress and defense mechanisms. Fluoride 49, 293-302.

Yadu, B., Chandrakar, V., Meena R. K., Keshavkant, S., 2017: Glycinebetaine reduces oxidative injury and enhances fluoride stress tolerance via improving antioxidant enzymes, proline and genomic template stability in Cajanus cajan L. South African Journal of Botany 111, 68-75.

Yang, Y., Treat, M. B., He, N., Lick, S. D., Zimniak, P., Awasthi, Y. C., Boor, P. J., 2004: Glutathione-S-transferase A4 modulates oxidative stress in endothelium: possible role in human atherosclerosis. Atherosclerosis 173, 211-221.

Ye, N., Zhu, G., Liu, Y., Zhang, A., Li, Y., Liu, R., Shi, L., Jia, L., Zhang, J., 2012: Ascorbic acid and reactive oxygen species are involved in the inhibition of seed germination by abscisic acid in rice seeds. Journal of Experimental Botany 63, 1809-1822. 